\title{
PROTEINS AND ENZYME ACTIVITIES IN THE BLOOD OF COWS IN LATE PREGNANCY AND IN THEIR FOETUSES
}

\author{
J. BOUDA, P. JAGOS
}

Department of Diagnosis, Therapy and Prophylaxis of Animal Diseases, University of Veterinary Science, 61242 Brno

Received fanuary 22, 1979

\begin{abstract}
Bouda J., P. Jagos: Proteins and Enzyme Activities in the Blood of Cows in Late Pregnancy and in Their Foetuses. Acta vet. Brno, 48, 1979: 15-18.

Experiments involving 20 cows in late pregnancy and their foetuses were conducted to study the total serum proteins and their fractions. Further activities of GOT, AP, LDH and gamma-GT were measured in maternal and foetal plasma.

The total serum protein of the foetuses amounted $42 \mathrm{~g} / 1$ and was significantly lower $(P<0.01)$ than that of their mothers. These low total protein levels in foetal serum were connected with low $\gamma$-globulin levels amounting $1.1 \mathrm{~g} / 1$ as compared to $22.6 \mathrm{~g} / \mathrm{l}$ found in maternal serum. In the foetal sera higher levels of albumin and $\alpha$ globulins were found. Immunoglobulins measured by the turbidimetric method in the foetal and maternal sera correlated with their $\gamma$-globulin content.

Activity of the maternal plasma GOT surpassed that of the foetal enzyme three times. The activities of maternal plasma LDH and $\gamma$-GT were higher $(P<0.01)$ than those of the foetal plasma enzymes. On the other hand, significantly higher $(P<0.01)$ AP activity was found in the foetal plasma as compared to the maternal plasma enzyme activity.
\end{abstract}

Blood, plasma, serum, albumin, $\alpha-, \beta-, \gamma$-globulin, Ig, GOT, alkaline phosphatase, LDH, $\gamma$-glutamyltranspeptidase.

Numerous experimental data have shown that the blood serum of newborn calves contains almost no $\gamma$-globulin. As early as $1892 \mathrm{Ehrlich}$ proved that the maternal antibodies are transferred to the newborn calf by colostrum. The postnatal development of animals with the syndesmochorial type of placenta is dependent upon the physiological and immunological condition of their mothers (Pribyl 1963; Fey 1972; Logan 1977; Hajdu et al. 1977). The total protein amount and protein fractions in the blood serum of foetuses and newborn calves prior to feeding colostrum are substantially lower than those found in their mothers (Baetz et al. 1971; Boguth 1953; Piskač 1961; Bárta 1962; Hojovcová 1965).

Investigations into the foetal plasma enzyme activities indicated the GOT activity to be by about $50 \%$ lower as compared to data for the adult cattle (Baetz et al. 1971). Similarly, lower GOT activity was found in calves prior to feeding colostrum (Maděrová et al. 1960; Grün and Klötzer 1973). On the other hand, activity of the alkaline phosphatase in the foetal plasma was found to increase with age and to surpass remarkably the values found in the dams (Baetz et al. 1971). From the diagnostic point of view great attention has been recently given to $\gamma$-glutamyl-transpeptidase $(\gamma-G T)$. No data concerning this enzyme in calf foetuses are as yet available.

The aim of the present experiment was to study the relationships between the maternal and foetal serum protein levels, serum protein fractions, and plasma enzyme activities in cattle.

\section{Materials and Methods}

For experiments, 20 healthy cows of the Czech spotted breed in late pregnancy and their 8-9-month-old foetuses were employed. The average body mass of the foetuses was $32.1 \mathrm{~kg}$ ranging from 24.5 to $43.0 \mathrm{~kg}$. The foetuses were extracted by Caesarean section at the Department of 
Reproduction and Surgery of Farm Animals in order to obtain the foetal sera. Blood samples were collected from v. jugularis of the dams and from a. carotis of the foetuses.

The total protein levels were measured in maternal and foetal serum fotometrically using the Bio-Test (Biuret method) by Lachema, Brno. Electrophoretic separations of serum proteins on acetate foils using the Microphor Boskamp apparatus was conducted for 20 minutes. The protein fractions were evaluated using the Densiscan by Kipp and Zonen.

Serum immunoglobulins were determined by the turbidimetric method using the zinc-sulphate agent according to McEvan et al. (1970).

Activities of plasma GOT, AP $\gamma$-GT were determined fotometrically using the Bio-Tests by Lachema, Brno. The LDH activity was measured using the kit Sevac-LDH by Imuna, Sarišské Michal'any.

Table 1

Total proteins, their fractions and immunoglobulins in the serum of 20 cows and their foetuses

\begin{tabular}{|c|c|c|c|}
\hline \multirow{2}{*}{ Parameter under study } & Foetuses & Cows & \\
\hline & $\bar{x}$ & $\bar{x}$ & \\
\hline $\begin{array}{l}\text { Total protein }(\mathrm{g} / \mathbf{l}) \\
\text { Albumin }(\mathrm{g} / \mathbf{l}) \\
\alpha \text {-globulin }(\mathbf{g} / \mathbf{l}) \\
\beta \text {-globulin }(\mathbf{g} / \mathbf{l}) \\
\gamma \text {-globulin }(\mathbf{g} / \mathbf{l}) \\
\text { Ig (U.) }\end{array}$ & $\begin{array}{r}42.0 \pm 8.0 \\
22.9 \pm 4.4 \\
13.8 \pm 5.5 \\
4.2 \pm 2.4 \\
1.1 \pm 1.1 \\
15 \pm 1.0\end{array}$ & $\begin{array}{c}74.0 \pm 9.0 \\
36.1 \pm 7.8 \\
5.9 \pm 2.0 \\
9.4 \pm 3.3 \\
22.6 \pm 5.3 \\
38.8 \pm 11.0\end{array}$ & $\begin{array}{l}++ \\
++ \\
++ \\
- \\
++ \\
++\end{array}$ \\
\hline
\end{tabular}

Note: $P<0.01=++$

Table 2

Enzyme activities in the plasma of 20 cows and their foetuses

\begin{tabular}{|c|c|c|c|}
\hline Parameter under study & Foetuses & Cows & $P$ \\
\hline $\begin{array}{l}\text { GOT }(U / 1) \\
\text { AP }(U / 1) \\
\text { LDH }(U / 1) \\
\gamma \text {-GT }(U / 1)\end{array}$ & $\begin{aligned} 7.5 & \pm 2.7 \\
223.8 & \pm 110.2 \\
524.4 & \pm 150.3 \\
18.1 & \pm 9.7\end{aligned}$ & $\begin{aligned} 21.7 & \pm 5.0 \\
61.8 & \pm 51.5 \\
1008.7 & \pm 163.7 \\
40.5 & \pm 14.0\end{aligned}$ & $\begin{array}{l}++ \\
++ \\
++ \\
++\end{array}$ \\
\hline
\end{tabular}

Note: $P<0.01=++$

\section{Results}

The average values for total proteins, their fractions and immunoglobulins are given in Table 1. The total protein amount of the foetal serum was significantly lower than that of the maternal serum. Accordingly, low $\gamma$-globulin content was found in the foetal serum amounting $1.1 \mathrm{~g} / 1$, while in the maternal serum $22.6 \mathrm{~g} / 1$ and this high amount contributed to substantially higher total protein content. The Ig levels corresponded well with the $\gamma$-globulin content found in the experimental animals. In foetal serum higher albumin and $\alpha$-globulin levels were found. Differences in the foetal and maternal protein fractions were significant $(P<0.01)$ except for the $\beta$-globulins.

The activities of plasma GOT, AP, LDH and je-GT are given in Table 2. The foetal GOT activity was about 3 times lower than that of the maternal enzyme. The foetal LDH and $\gamma$-GT activities were about half the values found in maternal plasma. On the other hand, much higher AP activity was found in plasma of the foetuses. All the above-mentioned differences were significant $(P<0,01)$. 


\section{Discussion}

Our study revealed remarkable differences in the amount of serum proteins and their fractions of pregnant cows and their foetuses. These data are in good agreement with those of Baetz et al. (1971). These authors found the total protein amount of the foetal serum to increase from $2.6 \mathrm{~g} / 100 \mathrm{ml}$ in 5-month-old foetuses to $4.0 \mathrm{~g} / 100 \mathrm{ml}$ in the 8-month-old ones. The total protein concentration in serum of foetuses in our experiment did not differ from its values found in the newborn calves prior to the intake of colostrum (Jagoš et al. 1977, 1978).

The total protein in the serum of foetuses consisted of $55 \%$ albumin, $33 \%$ $\alpha$-globulin and of $3 \% \gamma$-globulin. The greatest differences between the maternal and foetal sera were noted in the content of $\alpha$ - and $\gamma$-globulin. Immunoglobulins correlated with the $\gamma$-globulin content.

Earlier workers reported on the absence of globulin in the serum of calves prior to feeding colostrum. Nevertheless, in the present work $\gamma$-globulins were found in the foetal serum ranging from 0 to $2.9 \mathrm{~g} / 1$ (average $1.1 \mathrm{~g} / 1$ ). This value is lower than that reported by Baetz et al. (1971). At present, it is thought that some antibody synthesis occurs also in foetuses, probably after transplacental transfer of antigens.

In our study only cows showing no clinical signs of illness were included. This was important for the determination of enzyme activities in pregnant cows and their foetuses. The GOT activity found in the foetuses was not only significantly lower than in their mothers but also lower than in calves after birth (Jagoš et al. $1977,1978)$. The GOT activity in the maternal plasma oscillated within the reference values (Jagoš et al. 1975). Similar relationship of the maternal and foetal GOT found also Baetz et al. (1971) although they noted somewhat higher activities of this enzyme for the foetuses.

In foetuses the LDH and $\gamma$-GT activities were about half the values found in their mothers. The maternal LDH activity was within the reference values (Jagoš et al. 1975) whereas the $\gamma$-GT was found to be slightly elevated. The finding of more than three times higher AP activity in foetuses is not surprising as this phenomenon in young animals (Haschen 1970; Šlesinger 1970) is connected with growth of the bones.

\section{Bílkoviny a aktivita enzymů $v$ krvi vysokobřezích krav a jejich fétů}

V krevním séru 20 vysokobřezích krav a jejich fétů byla stanovena celková bílkovina a její frakce. $Z$ enzymů v krevní plazmě byla stanovena aktivita GOT, $\mathrm{AP}, \mathrm{LDH}$, gama-GT.

Celková bílkovina $\mathrm{v}$ krevním séru fétů dosáhla $42 \mathrm{~g} / 1$ a byla významně nižší než u krav $(P<0,01)$. Nízké koncentrace celkové bílkoviny u fétů byly $\mathrm{v}$ souvislosti s nízkou koncentrací gama-globulinů, na které připadlo $1,1 \mathrm{~g} / 1$, zatímco u krav 22,6 g/l. V séru fétů byly výrazně vyšší hodnoty albuminů a alfa-globulinů.

Aktivita plazmatické GOT u fétů byla 3krát nižší než u krav. Přibližně poloviční aktivity LDH a gama-GT byly i v krevní plazmě fétů $(P<0,01)$. Významně vyšších aktivit dosahovala $A P$ u fétů při srovnání s krávou $(P<0,01)$.

Imunoglobuliny určené turbidimetrickou metodou v krevním séru fétů a jejich matek korelovaly s obsahem gama-globulinů. 
Белки и активности энзимов в крови коров в высокой стадии беременности и их зародышей

В кровяной сыворотке 20 коров в высокой стадии беременности и их зародышей определялся общий белок и его фракции. На основе энзимов в кровяной плазме устанавливалась активность ГОТ, АФ, ЛДГ гамма-ГТ.

Общий белок в кровяной сыворотке зародышей достиг 42 г/л и был существенно ниже чем у коров $(\mathrm{P}<0,01)$. Низкая концентрация общего белка у зародышей имела место в связи с низкой концентрацией гамма-глобулинов, на которые приходилось $2,7 \%$, между тем как у коров $30,5 \%$. В сыворотке зародышей имелись существенно более высокие величины альбуминов и альфа-тлобулинов.

Активность плазматической ГОТ зародышей по сравнению с коровами была 3 раза ниже. Приблизительно на половину ниже имели место ақтивности ЛДГ и гамма-ГТ, также в кровяной плазме зародышей $(\mathrm{P}<0,01)$. Существенно более высокой активности достигала АФ зародышей по сравнению с коровой $(\mathrm{P}<0,01)$.

\section{References}

BAETZ, A. L. - HUBBERT, W. T. - GRAHAM, C. K.: Changes in plasma levels of proteins and enzymes in the fetal calf during gestation. Biol. Neonate, 18, 1971: 348-355.

BÁRTA, O.: Sledování vlivu ustájení a zpủsobu odchovu na zdravotní stav a obranyschopnost telat. (Project report), VÚCHS Rapotín, 1962, 63 pp.

BOGUTH, W.: Papierelektrophoretische Serumunteruschungen bei Haussäugetieren. Zbl. Vet. Med., 1, 1953: 168.

EHRLICH, P.: Ưber Immunität durch Vererbung und Säugung. Z. Hyg. Infektkr., 12, 1892: $183-203$.

FEY, H.: Colibacillosis in calves. Hans Huber Publishers, Bern, Stuttgart, Vienna, 1972: 147 pp.

GRƯN, E. - KLÖTZER, M.: Serumenzyme bei neugeborenen Tieren. 1. Mitt.: Verhalten bei neugeborenen Kälbern. Monatsh. Vet. Med., 28, 1973: 651-656.

HAJDU, S. - BLAHO, R. - HECKO, R.: Štúdium humorálneho imunitného systému hovädzieho dobytka $\mathrm{v}$ postnatálnom období. Imunoprofylaxia, 3, 1977: 38-52.

HASCHEN, R. J.: Enzymdiagnostik. VEB Gustav Fischer, Jena 1970, 251 pp.

HOJOVCOVÁ, M.: Bílkovinné spektrum a celková bílkovina krevního sérà skotu z různých fyzior logických pomèrù. $\mathrm{PhD}$. Thesis, veterinární fakulta Vysoké školy zemědělské, Brno 1965, $193 \mathrm{pp}$.

JAGOŠ, P. - BOUDA, J. - ILLEK, J. - HOFÍREK, B.: Rozpracování metabolických testů $\mathrm{k}$ určení skrytých poruch výměny látkové $\mathrm{u}$ dojnic $\mathrm{v}$ podmínkách průmyslových komplexủ. Project report, Vysoká škola veterinární, Brno 1975, 50 pp.

JAGOS, P. - BOUDA, J. - DVOKÁK, V. - HAMŚIK, V.: Metabolismus a jeho poruchy u telat ve vztahu $k$ metabolismu vysokobřezích krav. Předneseno na 2 . symposiu o metabolických poruchách u vysokoprodukčních dojnic, Smolenice 1. - 2.6.1977.

JAGOŠ, P. - BOUDA, J. - DVOǨ́K, V. - DVOŘÁ, R. - HAMŚÍK, V. - VALACH, Z.: Studium aktivity enzymů, hladiny vitamínů a bílkovin $\mathrm{v}$ různých fázích ontogeneze $\mathrm{u}$ telat při metabolických poruchách. Project report, Vysoká škola veterinární, Brno 1978, 84 pp.

LOGAN, E. F.: The influence of husbandry on colostrum yield and immunoglobulin concentration in beef cows. Brit. Vet. J., 133, 1977: 120-125.

MADĚROVÁ, V. - NEUMAN, V.: Transamináza kyseliny glutamové-oxaloctové a kyseliny glutamové-pyrohroznové v krevním séru klinicky zdravého skotu. Vet. Med., 5, 1960: 819-826.

MC EWAN, A. D. - FISHER, E. W. - SELMAN, J. E. - PENHALE, W. J.: A turbidity test for estimation of immune globulin levels in neonatal calf serum. Clin. Chim. Acta, 27, 1970: $155-163$.

PISKAČ, A.: Bílkovinné spektrum krevního séra hospodářských zviřat za některých fyziologických podmínek a patologických procesů. $\mathrm{PhD}$. Thesis, veterinární fakulta Vysoké školy zemědělské, Brno 1961, 216 pp.

PŘIBYL, E.: Choroby mláđat hospodářských zviřat. SZN Praha 1963, 230 pp.

ŠLESINGER, L.: Vliv pohlaví a stáŕí na dynamiku hladin anorganického fosforu a aktivitu alkalické fosfatázy $\mathrm{v}$ krevním séru telat od narození do stáŕi dvou rokủ. Vet. Med. (Praha), 1970: $179-184$. 